Brit. F. vener. Dis. (1967), 43, 249.

\title{
INTERPRETATION OF POSITIVE SEROLOGICAL TESTS FOR SYPHILIS IN PREGNANCY*
}

\author{
BY \\ ADETUNJI ADEOBA $\dagger$ \\ Lagos University Teaching Hospital, Nigeria
}

The remarkable decline in the incidence of syphilis in the first half of the 20th century tempted many observers to share the view of Illingworth (1959) that it was a disappearing disease. Since 1957, however, there has been an unmistakable upward trend in many parts of the world (Stallworthy and Bourne, 1966; Walter and Israel, 1965), and many cases of florid congenital syphilis have been reported (Woody, Sistrunk, and Platou, 1964). In 1960, the Registrar General's statistical review listed 935 deaths in England and Wales alone. This makes it desirable to review provisions for ante-natal care. The endemic state of syphilis in both Eire and Nigeria demonstrated in the present study emphasizes the importance of continuing routine serological tests for syphilis in pregnant women.

\section{Material and Methods}

Syphilis in ante-natal patients was surveyed between February, 1965, and July, 1966, in two hospitals dealing with women of similar social class-St. Kevin's Hospital, Dublin, Eire, and Suru-Lere Health Centre, Lagos, Nigeria.

In order, as far as possible, to eliminate difficulties arising from similarities between the appearances of syphilitic placentae and placentae from cases of hydrops foetalis, only $\mathrm{Rh}$-positive patients were considered.

3,670 such pregnant women were seen in the two countries, of whom 106 had a positive Wassermann reaction (WR) and Kahn test. Four further cases, one Jamaican at the Queen Elizabeth Hospital, Birmingham, and three Irish at the Altnagelvin

\footnotetext{
*Received for publication October 31, 1966.

+Present address: Good Hope Maternity Hospital, Rectory Rd, Sutton Coldfield, Warwicks.

Abbreviations used in the text are explained below:

PPR Price's Precipitation Reaction.

FTA $\quad$ Fluorescent Treponemal Antibody Test.

TPI Treponema pallidum Immobilization Test.

STS Serological Test for Syphilis.

BFP Biological False Positive.

L.U.T.H. Lagos University Teaching Hospital.

S.K.H. St. Kevin's Hospital.
}

Hospital, Londonderry, Northern Ireland, were investigated later and added to the series, making a total of 110 out of 3,674 (Table I, overleaf).

All the patients were systematically examined at their first visit for clinical evidence of syphilis, yaws, leprosy, acute infection, and collagen disease. Inquiries were also made about addiction to narcotic drugs.

The Nigerian patients found to be infected (but not the Irish) were immediately prescribed a 3-day course of $200 \mathrm{mg}$. "Nivaquine" (chloroquine hydrochloride) twice daily, and no further serological examinations were carried out for 6 weeks.

In cases with an initial positive result (in both countries), the Kahn test and WR were repeated and the Reiter protein complement-fixation test was performed as well. If the results had then become negative, no further investigations were made. When positive results were confirmed, a specimen of the patient's serum was forwarded to the Venereal Diseases Reference Laboratory, (VDRL) for TPI and FTA tests, and the husband was examined for clinical and serological evidence of syphilis.

In order to differentiate positive serological tests due to syphilis from those due to yaws, Nigerian women with positive TPI or FTA serum tests had a specimen of cerebrospinal fluid (CSF) taken in two separate test-tubes, one of which was preserved by deep freezing, while the other was examined by reagin tests and the RPCF test. If either was positive, the preserved CSF test-tube specimen was forwarded by air mail to the VDRL for TPI and FTA tests.

All the suspected cases were delivered by the writer and a specimen of the cord blood was examined for reagin antibodies in all except the BFP cases. Umbilical cord and placental tissues were taken for histological examination.

3 months after delivery, the blood of every infant whose mother had been classified as proved or 
TABLE I

SUMMARY OF RESULTS

\begin{tabular}{|c|c|c|c|}
\hline Clinic & Total No. of Patients Examined & WR and Kahn Positive & Final Classification \\
\hline $\begin{array}{l}\text { Suru-Lere Health Centre, } \\
\text { Lagos, Nigeria }\end{array}$ & $\begin{array}{l}\text { *920 (selected from approximately } \\
18,400 \text { patients, see below) }\end{array}$ & $95(10 \cdot 32$ per cent.) & $\begin{array}{lrl}\text { \&(a) Proved } & 5 & (0.55 \text { per cent. }) \\
\|(b) \text { Probable } & 8 & (0.95 \text { per cent. }) \\
(c) \text { BFP } & 82 & (8.82 \text { per cent. })\end{array}$ \\
\hline $\begin{array}{l}\text { St. Kevin's Hospital, } \\
\text { Dublin, Eire }\end{array}$ & 2,750 & $11(0.4$ per cent. $)$ & $\begin{array}{l}\text { T(a) Proved } \\
\text { (b) Probable } \quad(0 \cdot 14 \text { per cent.) } \\
\text { (Category not used for } \\
\text { Irish patients) } \\
\text { (c) BFP } \quad 7 \quad(0 \cdot 26 \text { per cent.) }\end{array}$ \\
\hline †Miscellaneous & 4 & 4 & $\begin{array}{l}\text { (a) Proved } \\
\text { (b) Probable } \\
\text { (c) Bil } \\
\text { (c) }\end{array}$ \\
\hline Total $\ddagger$ & 3,674 & 110 & $\begin{array}{l}\text { (a) Proved } 12 \\
\text { (b) Probable } 8 \\
\text { (c) BFP }\end{array}$ \\
\hline
\end{tabular}

* Only a small percentage of the total work done in the Suru-Lere Health Centre passed through the Professorial Clinic where these investigations were done. Selected problems were referred to this Professorial Clinic but all the WR and Kahn positive cases were seen. †Three Irishwomen and one Jamaican encountered and investigated by the writer in Northern Ireland.

$¥$ To this must be added:

(i) Thirteen husbands and two siblings proved syphilitic and treated (vide "Further Results")

(ii) Six syphilitic relatives of Case 6, Table II, considered separately in Table V.

§See Table III. $\quad$ ISee Table IV. Table II.

probably syphilitic (see below) was tested for reagin antibodies and the long bones were $x$-rayed. All apparently syphilitic babies then received an appropriate course of penicillin.

\section{Classification}

An arbitrary classification was adopted because of the particular problem of differentiating yaws from syphilis in Nigeria.

(a) Proved Syphilitic A diagnosis of indisputable syphilis was thought to be established if:

(1) IN NIGERIA:

(i) Both the serum and CSF gave positive results in two or more reagin tests as well as in the TPI or FTA test or both.

(ii) A CSF-positive FTA test alone or in combination with any of the reagin tests was accepted. (iii) Both the serum and CSF gave positive results for any two tests (RPCFT, TPI, or FTA).

(2) IN EIRE:

If the Nigerian criteria (below) for "very probably syphilitic" were fulfilled in Irish patients, they were regarded as cases of proved syphilis.
(3) IN BOTH NIGERIA AND EIRE:

There was any evidence of syphilitic infection in the baby resulting from the pregnancy.

(b) Probably Syphilitic (In Nigeria) This category was chosen for Nigerian cases in which the above criteria were not fulfilled, in that the CSF was negative but the serum was positive:

(i) In two of the reagin tests and either the TPI or FTA.

(ii) In any two tests (TPI, FTA, or RPCFT).

(c) Biological False Positives It was thought that syphilis was neither proved nor probable if the serum became free from reagin antibodies after the administration of anti-malarial drugs, or had negative TPI and FTA tests.

\section{Results}

There are summarized in Table $I$, and details are shown in Tables II, III, and IV. One of the four cases shown under "Miscellaneous" in Table I proved to have six syphilitic relatives (details in Table V, overleaf).

TABLE II

SERUM EXAMINATIONS OF SIX IRISH PATIENTS CLASSIFIED AS "PROVED SYPHILITIC" (TABLE I)

\begin{tabular}{|c|c|c|c|c|c|c|c|c|c|c|}
\hline Patient No. & $\ldots$ & . & $\ldots$ & .. & $1 *$ & $2 *$ & $3 *$ & $4^{*}$ & $5 t$ & $6+\ddagger$ \\
\hline $\begin{array}{l}\text { Kahn } \\
\text { WR } \\
\text { VDRL Slide } \\
\text { PPR } \\
\text { RCF } \\
\text { FTA } \\
\text { TPI }\end{array}$ & & & & & $\begin{array}{c}+++ \\
++ \\
++ \\
\text { Not done } \\
++ \\
+ \\
+\end{array}$ & $\begin{array}{c}++ \\
+++ \\
++ \\
\text { Not done } \\
\text { Not done } \\
+ \\
+\end{array}$ & $\begin{array}{c}+ \\
++ \\
+ \\
\text { Not done } \\
++ \\
+ \\
+\end{array}$ & $\begin{array}{c}++ \\
++ \\
+ \\
\text { Not done } \\
++ \\
+ \\
+\end{array}$ & $\begin{array}{l}+ \\
+ \\
+ \\
+ \\
+ \\
+ \\
+\end{array}$ & $\begin{array}{l}+ \\
+ \\
+ \\
+ \\
+ \\
+ \\
+\end{array}$ \\
\hline
\end{tabular}

- St. Kevin's Hospital, Dublin. See Figs 1, 2, 3 for details of Case 1.

Investigated, treated, and delivered by the writer at Altnagelvin Hospital, Londonderry, Northern Ireland (see Fig. 7).

$\ddagger$ All the available relatives of Case 6 were also examined, and her mother, three brothers, and two sisters were found to be infected (see Table V). 
TABLE III

SERUM AND CSF EXAMINATIONS OF FIVE NIGERIANS AND ONE JAMAICAN CLASSIFIED AS “PROVED SYPHILITIC" (TABLE I)

\begin{tabular}{|c|c|c|c|c|c|c|c|}
\hline Patient No. & . & $1^{*}$ & $2^{*}$ & $3 *$ & $4^{*}$ & $5^{*}$ & $6 t$ \\
\hline $\begin{array}{l}\text { Serum } \\
\text { Tests }\end{array}$ & $\begin{array}{l}\text { Kahn } \\
\text { WR } \\
\text { VDRL Slide } \\
\text { PPR } \\
\text { CF } \\
\text { FTA } \\
\text { TPI }\end{array}$ & $\begin{array}{c}+++ \\
++ \\
+ \\
+++ \\
+ \\
+ \\
+\end{array}$ & $\begin{array}{c}+++ \\
+++ \\
++ \\
++ \\
+ \\
+ \\
+\end{array}$ & $\begin{array}{l}++ \\
+ \\
++ \\
+ \\
+ \\
+ \\
+\end{array}$ & $\begin{array}{c}+ \\
\text { Neg. } \\
\text { Neg. } \\
\text { Neg. } \\
+ \\
\text { Not done } \\
\text { Not done }\end{array}$ & $\begin{array}{l}++ \\
+ \\
+ \\
+ \\
+ \\
+ \\
+\end{array}$ & $\begin{array}{l}+ \\
+ \\
+ \\
+ \\
+ \\
+ \\
+\end{array}$ \\
\hline $\begin{array}{l}\text { CSF } \\
\text { Tests }\end{array}$ & $\begin{array}{l}\text { Protein (mg. per cent.) } \\
\text { Cell count/cu. mm. } \\
\text { Kahn } \\
\text { WR } \\
\text { VDRL Slide } \\
\text { PPR } \\
\text { RPCF } \\
\text { FTA } \\
\text { TPI }\end{array}$ & $\begin{array}{c}90 \\
\\
50 \\
+ \\
\text { Neg. } \\
\text { Neg. } \\
+ \\
\text { Neg. } \\
+ \\
\text { Neg. }\end{array}$ & $\begin{array}{c}50 \\
\\
30 \\
+ \\
\text { Neg. } \\
\text { Neg. } \\
+ \\
\text { Neg. } \\
+ \\
\text { Neg. }\end{array}$ & $\begin{array}{c}45 \\
\\
35 \\
\text { Not done } \\
\text { Neg. } \\
\text { Neg. } \\
+ \\
\text { Neg. } \\
+ \\
\text { Neg. }\end{array}$ & Not done & $\begin{array}{c}\text { Lumbar } \\
\text { puncture } \\
\text { unsuccessful }\end{array}$ & Not done \\
\hline
\end{tabular}

*Lagos, Nigeria. See Figs 4 and 5 for $x$-rays of Case 4, and Fig. 6 for $x$-rays of Case 1.

tCase 6, a Jamaican, was investigated at the Queen Elizabeth Hospital, Birmingham.

TABLE IV

SERUM AND CSF EXAMINATION ON EIGHT NIGERIANS CLASSIFIED AS “PROBABLY SYPHILITIC” (TABLE I)

\begin{tabular}{|c|c|c|c|c|c|c|c|c|c|}
\hline Patient No. & . & 1 & 2 & 3 & 4 & 5 & 6 & 7 & 8 \\
\hline $\begin{array}{l}\text { Serum } \\
\text { Tests }\end{array}$ & $\begin{array}{l}\text { Kahn } \\
\text { WR } \\
\text { VDRL Slide } \\
\text { PPR } \\
\text { RPCF } \\
\text { FTA } \\
\text { TPI }\end{array}$ & $\begin{array}{c}++ \\
+ \\
+ \\
\text { Not done } \\
+ \\
+ \\
+\end{array}$ & $\begin{array}{c}+++ \\
++ \\
++ \\
+ \\
+ \\
+ \\
+\end{array}$ & $\begin{array}{c}+ \\
+ \\
+ \\
+ \\
+ \\
\text { Neg. } \\
\text { No valid } \\
\text { test }\end{array}$ & $\begin{array}{c}+ \\
++ \\
++ \\
++ \\
+ \\
+ \\
\text { No valid } \\
\text { test }\end{array}$ & $\begin{array}{c}+++ \\
+ \\
++ \\
+ \\
+ \\
+ \\
\text { No valid } \\
\text { test }\end{array}$ & $\begin{array}{l}+ \\
+ \\
+ \\
+ \\
+ \\
+ \\
+\end{array}$ & $\begin{array}{c}+t+ \\
+++ \\
+ \\
+ \\
+ \\
\text { Not done } \\
\text { Not done }\end{array}$ & $\begin{array}{c}+++ \\
+++ \\
++ \\
++ \\
++ \\
\text { Not done } \\
\text { Not done }\end{array}$ \\
\hline $\begin{array}{l}{ }^{*} \text { CSF } \\
\text { Tests }\end{array}$ & $\begin{array}{l}\text { Protein (mg. per cent.) } \\
\text { Cell count/cu. mm. } \\
\text { Kahn } \\
\text { WR } \\
\text { VDRL Slide } \\
\text { PPR } \\
\text { RPCF } \\
\text { FTA } \\
\text { TPI }\end{array}$ & $\begin{array}{c}10 \\
2 \\
\text { Neg. } \\
\text { Neg. } \\
\text { Not done } \\
\text { Neg. } \\
\text { Neg. } \\
\text { Not done } \\
\text { Not done }\end{array}$ & $\begin{array}{c}5 \\
1 \\
\text { Neg. } \\
\text { Neg. } \\
\text { Neg. } \\
\text { Neg. } \\
\text { Neg. } \\
\text { Not done } \\
\text { Not done }\end{array}$ & $\begin{array}{c}20 \\
15 \\
t \\
t \\
\text { Neg. } \\
\text { Neg. } \\
\text { Not done } \\
\text { Not done }\end{array}$ & $\begin{array}{c}4 \\
1 \\
\text { Neg. } \\
\text { Neg. } \\
\text { Neg. } \\
\text { Neg. } \\
\text { Neg. } \\
\text { Not done } \\
\text { Not done }\end{array}$ & $\begin{array}{c}5 \\
2 \\
\text { Neg. } \\
\text { Neg. } \\
\text { Neg. } \\
\text { Neg. } \\
\text { Neg. } \\
\text { Not done } \\
\text { Not done }\end{array}$ & $\begin{array}{l}\text { Not done } \\
\text { Not done } \\
\text { Neg. } \\
\text { Neg. } \\
\text { Neg. } \\
\text { Neg. } \\
\text { Neg. } \\
\text { Not done } \\
\text { No valid } \\
\text { test }\end{array}$ & $\begin{array}{c}10 \\
2 \\
\text { Neg. } \\
\text { Neg. } \\
\text { Neg. } \\
\text { Neg. } \\
\text { Neg. } \\
\text { Not done } \\
\text { Not done }\end{array}$ & \\
\hline
\end{tabular}

*In CSF specimens, FTA and TPI examinations were done only when reagin tests, protein estimations, and cell counts provided the indication.

tPositive becoming negative.

Symptoms Very few clinical manifestations of syphilis were found, and no chancres were seen despite repeated searches. The only significant clinical finding was a syphilide rash in Case 1 (Table II) on the genitalia, inner aspect of the thighs, and the chest. This rash was copper-tinged, macular, symmetrical, polymorphic, and not itchy (Fig. 1, overleaf).

A dark-ground microscope examination was not possible, so that the lesions were not examined for treponemata.

History A history of previous stillbirths and second trimester abortions was obtained from eleven out of the twenty cases included in Tables II and III, but exposure to infection was rarely admitted.
Age The average age was 21 years, the oldest woman (Irish) being 46 and the youngest (Nigerian) 18 years old.

Previous Pregnancies About a quarter of the cases were primigravidae.

Regional Distribution Among Nigerians there appeared to be a preponderance of cases from the Mid-Western region. All the Irish patients investigated lived in Dublin or within Dublin County, except the three cases from Londonderry. There was also the one Jamaican.

Socio-Economic Group Fifteen of the twenty cases in Tables II and III belonged to a low income group and the rest to the middle income group. Both 
TABLE V

SEROLOGICAL EXAMINATIONS OF BLOOD FROM CASE 6 (TABLE II) AND RELATIVES

\begin{tabular}{|c|c|c|c|c|c|c|c|c|}
\hline \multirow{2}{*}{ Subject } & \multirow{2}{*}{ Age (yrs) } & \multicolumn{6}{|c|}{ Serum Tests } & \multirow[b]{2}{*}{ TPI } \\
\hline & & Kahn & WR & VDRL Slide & PPR & RPCF & FTA & \\
\hline Case 6, Table II & 18 & + & + & Serum diluted $1 / 16$ & + & + & + & + \\
\hline Husband & 27 & Neg. & Neg. & Neg. & Neg. & Neg. & Neg. & Neg. \\
\hline $\begin{array}{l}\text { Cord blood of stillborn } \\
\text { anencephalic infant }\end{array}$ & 0 & Not done & + & Not done & + & + & Not done & Not done \\
\hline $\begin{array}{l}\text { Mother } \\
\text { Father }\end{array}$ & $\begin{array}{l}54 \\
59\end{array}$ & $\begin{array}{c}+ \\
\text { Neg. }\end{array}$ & $\begin{array}{c}+ \\
\text { Neg. }\end{array}$ & 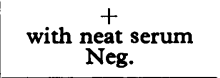 & $\begin{array}{c}+ \\
\text { Neg. }\end{array}$ & $\begin{array}{l}\text { Neg. } \\
\text { Neg. }\end{array}$ & $\begin{array}{c}+ \\
\text { Neg. }\end{array}$ & $\begin{array}{c}+ \\
\text { Neg. }\end{array}$ \\
\hline $\begin{array}{l}\text { Brother } \\
\text { Brother } \\
\text { Brother }\end{array}$ & $\begin{array}{l}30 \\
28 \\
26\end{array}$ & $\begin{array}{l}+ \\
+ \\
+\end{array}$ & $\begin{array}{l}+ \\
+ \\
+\end{array}$ & $\begin{array}{l}+ \\
+ \\
+\end{array}$ & $\begin{array}{l}+ \\
+ \\
+\end{array}$ & $\begin{array}{l}+ \\
+ \\
+\end{array}$ & $\begin{array}{l}+ \\
+ \\
+\end{array}$ & $\begin{array}{l}+ \\
+ \\
+\end{array}$ \\
\hline $\begin{array}{l}\text { Sister } \\
\text { Sister }\end{array}$ & $\begin{array}{l}33 \\
24 \\
\end{array}$ & + & + & + & $\begin{array}{l}+ \\
+ \\
\end{array}$ & + & $\begin{array}{l}+ \\
+\end{array}$ & $\begin{array}{l}+ \\
+ \\
\end{array}$ \\
\hline $\begin{array}{l}\text { Niece } \\
\text { Niece } \\
\text { Niece } \\
\text { Niece }\end{array}$ & $\begin{array}{l}7 \\
6 \\
5 \\
2\end{array}$ & $\begin{array}{l}\text { Neg. } \\
\text { Neg. } \\
\text { Neg. } \\
\text { Neg. }\end{array}$ & $\begin{array}{l}\text { Neg. } \\
\text { Neg. } \\
\text { Neg. } \\
\text { Neg. }\end{array}$ & $\begin{array}{l}\text { Neg. } \\
\text { Neg. } \\
\text { Neg. } \\
\text { Neg. }\end{array}$ & $\begin{array}{l}\text { Neg. } \\
\text { Neg. } \\
\text { Neg. } \\
\text { Neg. }\end{array}$ & $\begin{array}{l}\text { Neg. } \\
\text { Neg. } \\
\text { Neg. } \\
\text { Neg. }\end{array}$ & $\begin{array}{l}\text { Neg. } \\
\text { Neg. } \\
\text { Neg. } \\
\text { Neg. }\end{array}$ & $\begin{array}{l}\text { Neg. } \\
\text { Neg. } \\
\text { Neg. } \\
\text { Neg. }\end{array}$ \\
\hline
\end{tabular}

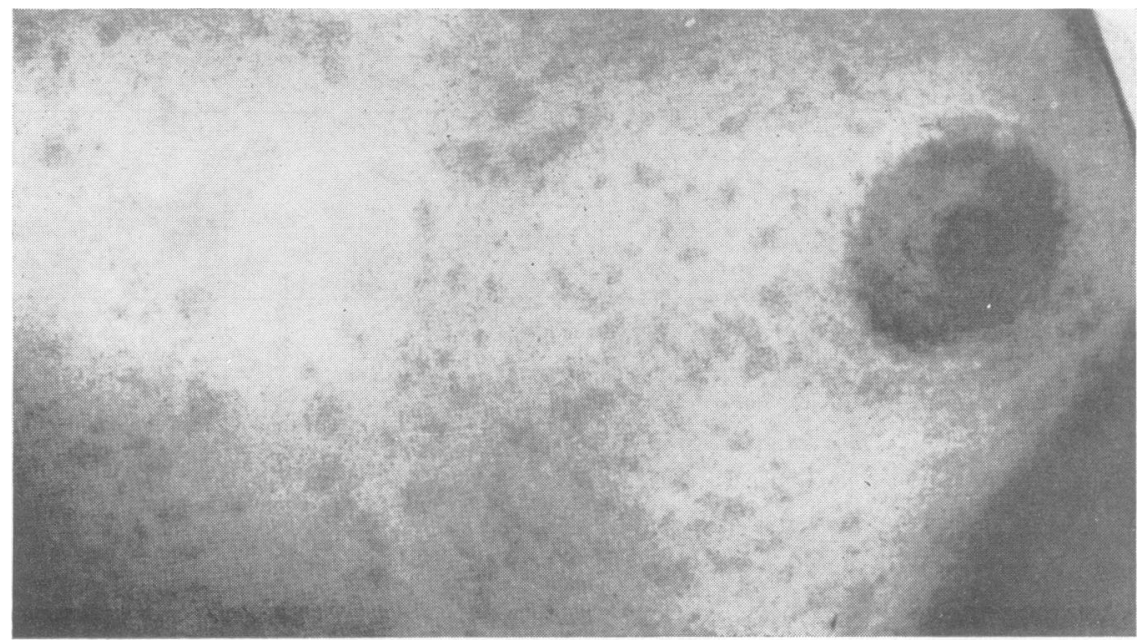

FIG. 1.-Syphilide rash from Case 1 (Table II).

the Health Centre in Lagos and S.K.H. in Eire are principally intended for such persons.

Husband's Occupation These were diverse; very many were unskilled labourers, and only two were sailors.

Serological Examination Among the 110 patients with a positive initial WR and Kahn test, 3.8 per cent. of the Irish and 4.7 per cent. of the Nigerians were eventually classified as having "proved syphilis" on serological evidence. $7 \cdot 5$ per cent. of the Nigerians had "probable syphilis".

Cord Blood This was examined in all twenty cases classified as proved and probably syphilitic.
Five babies had positive WR, VDRL, and PPR, one being a stillborn anencephalic. 3 months after delivery, only two remained sero-positive and both were treated.

Placenta The average weight of the twenty placentae was $1.9 \mathrm{lb}$. (range $\frac{1}{3}$ to $\frac{1}{4}$ of the birth weight).

Histological evidence of syphilitic affection of the placenta must include most of the following criteria: MACROSCOPIC: Bulky, greasy, pale appearance; a quarter or more of the weight of the foetus.

MICROSCOPIC: Perivascular fibrosis.

Endarteritis obliterans.

Inflammatory exudates. 
All the "proved" and "probable" cases were fully treated before delivery and therefore syphilitic placentae were not anticipated. Some of the histological findings included dystrophic calcification, atrophic villi, thickening of the blood vessels, and fine-patterned fibrosis. These non-specific findings appear to form the picture which should be expected in treated cases. Levaditi staining gave no useful results.
The nearest approach to the classical picture was seen in the histological report on the placenta of a stillborn macerated foetus (Case 1, Table II), which was supported by Prof. P. J. Holland of Dublin and Dr C. W. Taylor of Birmingham (Fig. 2).

Cord The cord tissues in all twenty cases showed little histological evidence of syphilis. Fig. 3 is a typical example.

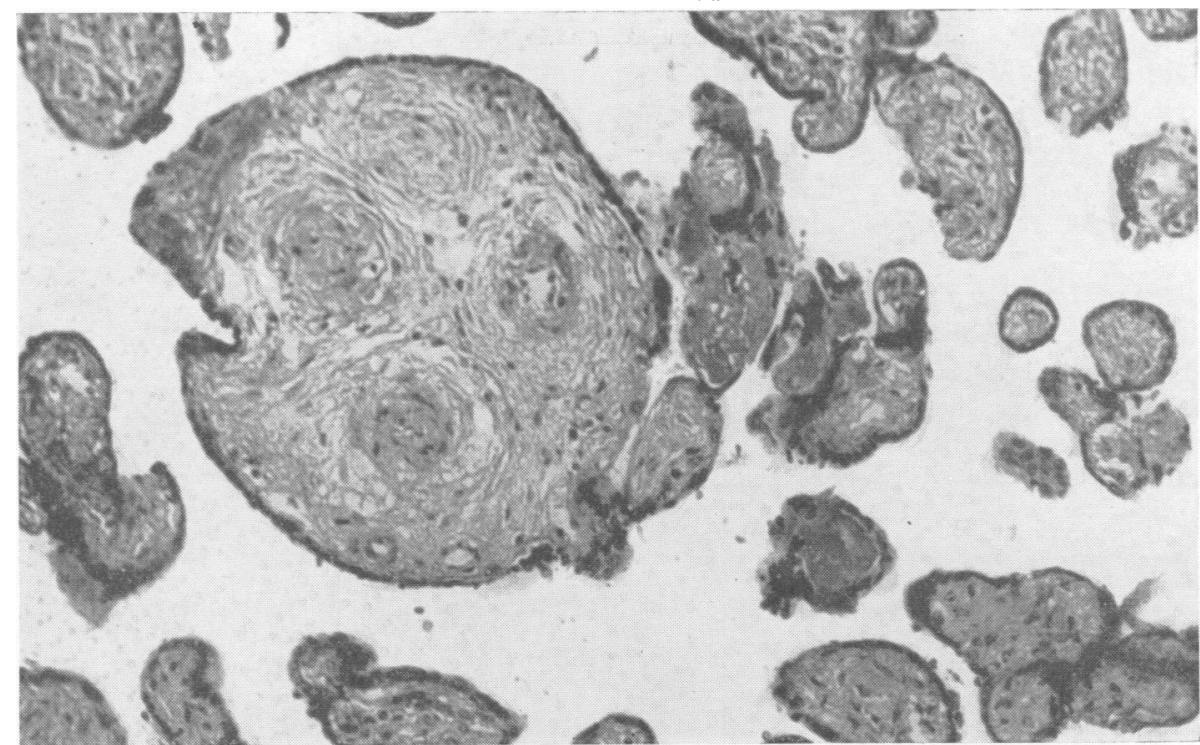

FIG. 2.-Case 1 (Table II). Section of placenta, showing dystrophic calcification. Some villi are large with stromal fibrosis, diminution of foetal vessels, and endarteritis obliterans.

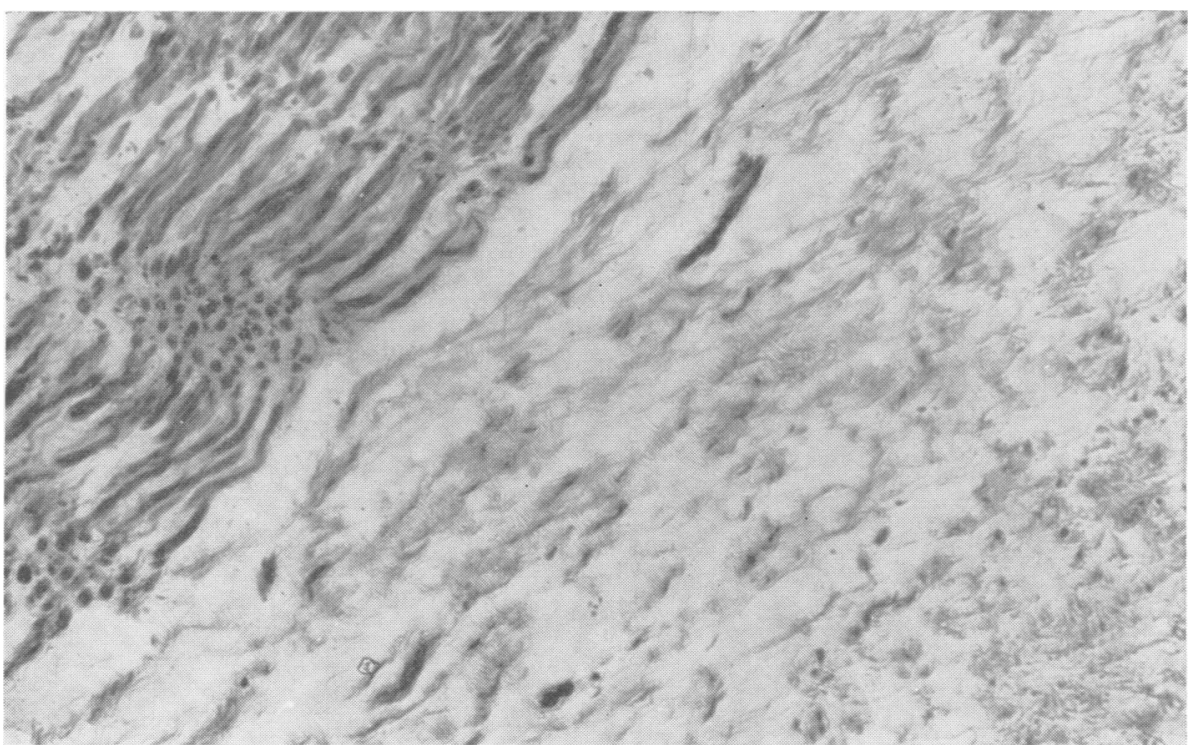

FIG. 3.-Case 1 (Table II). Section of umbilical cord, showing part of thick artery wall (lower right) and markedly oedematous and cellular Wharton's jelly (left). There are small haemorrhages around the vessels. 
Radiology Only two infants showed evidence of syphilis on $x$ ray (Figs $4,5,6$ ).

Biological False Positives These were seen in eight Irish and 59 Nigerian patients. 45 of the latter were accepted as having chronic malaria because of negative serological findings after the administration of anti-malarial drugs; in the other fourteen cases, no definite cause was found.

Yaws 23 Nigerians had a past history of yaws and 21 of these showed stigmata of yaws, or gave a definite confirmatory history. Sixteen of the 23 appeared to have had some sort of hospital treatment.

Pre-Eclamptic Toxaemia (PET) More than half (twelve out of twenty) of the women classified as proved and probably syphilitic had mild to moderate PET.

\section{Evidence of Infection in Relations of the Patient}

Thirteen of the twenty husbands of the women with proved and probable syphilis were sero-positive; the remaining seven were sero-negative despite repeated testing. All were treated by the author with 10 megaunits penicillin over 10 days.

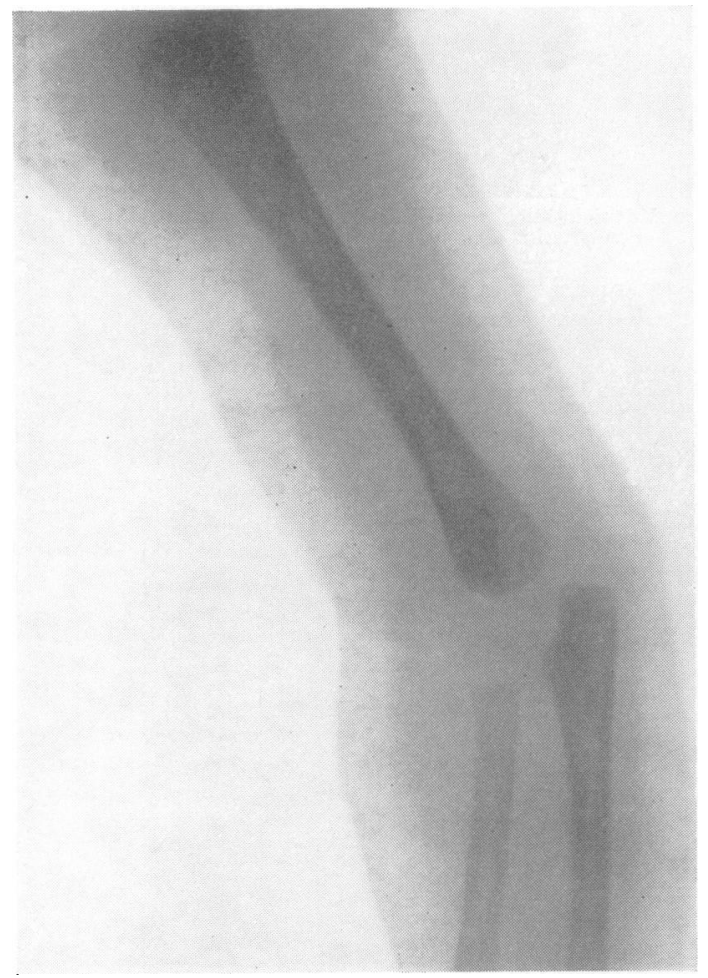

FIG. 4.-Case 4 (Table III). Periosteal reaction along lateral aspect of right humeral shaft.

FIg. 5.-Case 4 (Table III). Periosteal reaction on medial aspect of both tibiae, with some bowing.

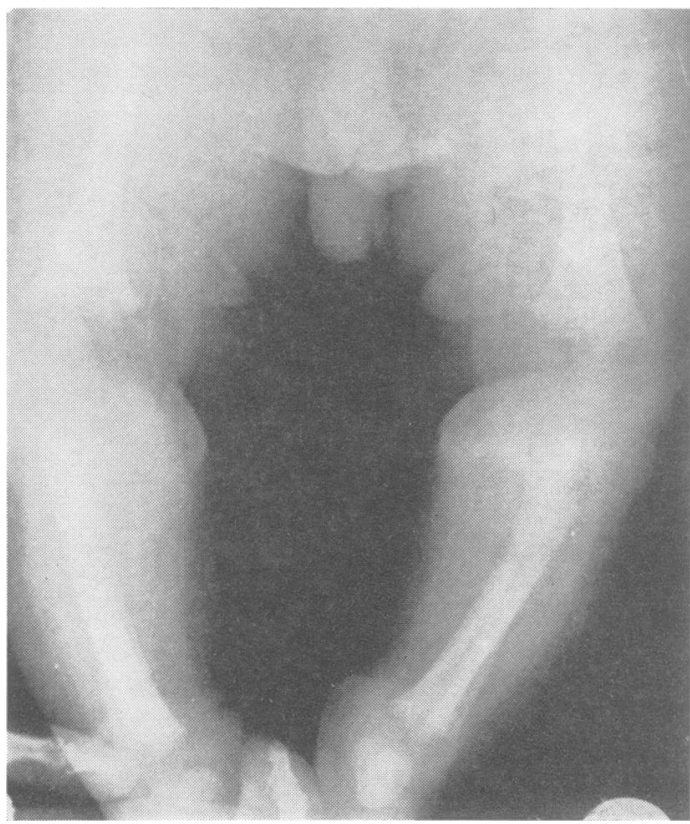

FIG. 6.-Case 1 (Table III). Periosteal reaction in leg bones. 
Case 4 (Table II). This woman mentioned that her 20 -year-old first daughter had been treated by the family doctor for rheumatoid arthritis for 2 years. The daughter was strongly sero-positive and treatment with procaine penicillin brought a welcome remission of symptoms, the true diagnosis being syphilitic arthritis.

Congenital Syphilis This was found in two of the twenty women.

Case 5 (Table II). This woman has clinical stigmata of congenital syphilis as well as positive serum tests. Her Hutchinsonian teeth are shown in Fig. 7. Her infant was sero-negative and did not require treatment.

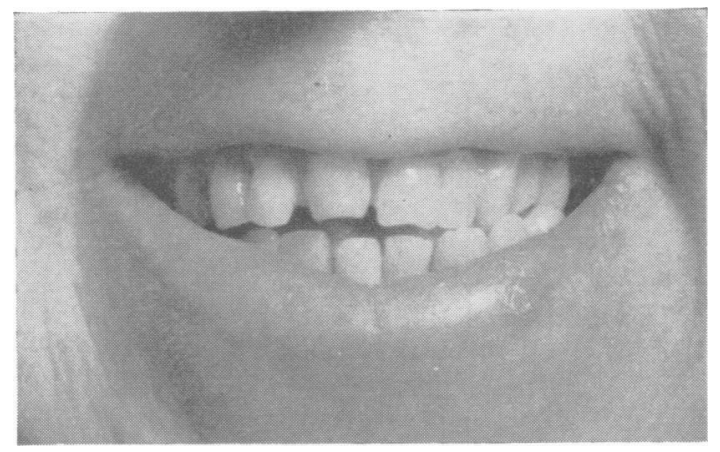

FIG. 7.-Case 5 (Table II), showing Hutchinsonian teeth.

Case 6 (Table II). The results of serological examinations of blood from the husband, infant, father, mother, five siblings, and four nieces are shown in Table V.

Foetal Loss Six Nigerians and one Jamaican miscarried between the 25th and 30th weeks, and in one Irish woman and one Nigerian intra-uterine death occurred between the 38th week and term.

Case 1 (Table II). An Irishwoman aged 20 was diagnosed early and treated with two courses of 10 mega-units procaine penicillin at the 18th and 37th weeks of pregnancy, but intra-uterine death occurred at term. She remained strongly sero-positive with a syphilitic rash (Figs 1,2, 3). The foetus was judged to be infected from histological examination.

Case 6 (Table II). This Jamaican woman went into spontaneous labour at approximately the 30th week. The intra-uterine death was not thought to be due to syphilis, as $x$-ray examination revealed a tiny foetus in the midst of a great mass of fibroids, and the patient had suffered from pregnancy toxaemia which had failed to respond to rest in bed and $\alpha$-methyl dopa (250 mg. three times a day) from approximately the 26 th week. This was the only foetal loss for which there were associated causes.

\section{Discussion}

To meet the need to be constantly on the alert for this protean disease (Greenhill, 1960), every pregnant woman should have a WR and Kahn test performed at her first ante-natal clinic attendance (Browne and McClure Browne, 1960; Donald, 1964); Cunningham (1958) recommended that these tests should also be performed in the fifth month.

The usual reagin tests, which may lead to a diagnosis of syphilis but do not firmly establish it, generally become positive from about the 6th to the 8th week after a primary infection (Boyd, 1961; Jeffcoate, 1962, 1966) and are always very strongly positive by the end of the third month (French and Macleod, 1963).

The present series yielded $110(2 \cdot 8$ per cent.) positive results, the distribution between Irish and Nigerian patients being shown in Table I. This should be compared with 0.36 per cent. recorded by the Ministry of Health in a representative sample of specimens from 90,080 expectant mothers and 0.71 per cent. in 2,802 consecutive expectant mothers examined at the Hammersmith Hospital (Browne and McClure Browne, 1960).

More sensitive serological tests (FTA and TPI) should always be performed to confirm evidence of infection (Fiumara, 1960). Wilkinson and Sequeira (1955) found that 27.5 per cent. of 244 sero-positive ante-natal patients gave negative TPI reactions. This result cannot be compared with the present series because the TPI test was not carried out in all my cases. Tables II and III show that the RPCF test is the best confirmatory test when the TPI and FTA tests cannot be done or are too expensive.

Initial Sero-Negative Tests The following case demonstrates that a positive reagin test should arouse suspicion, even if obtained only once during pregnancy.

Case 4 (Table III). When first seen at the ante-natal clinic this woman was about 36 weeks pregnant and was Kahn-positive. On four subsequent occasions she was sero-negative in every test (except the TPI and FTA, which were not done). She was therefore presumed to be biologically false positive and was not treated. Fortunately, however, the cord blood was tested and was found to be positive to VDRL and PPR, and 3 months later the baby's own blood was positive to WR, Kahn, VDRL, PPR, and RPCFT. $X$ rays of the long bones confirmed syphilitic infection (Figs 4 and 5) and the placental tissue also showed evidence of infection. Both mother and infant were subsequently treated.

This case may have been a fresh infection, but sero-negativity during the initial phase of a syphilitic infection is well documented and the antibody response may take 4 weeks or more to develop (Haines and Taylor, 1962). The higher infectivity of the disease during this phase makes the foetal involvement more easily understood. 
Biological False Positive Reactions been recorded in association with:

(i) Acute infectious fevers, smallpox vaccination, and T.A.B. inoculation (Price, 1955).

(ii) Iron deficiency anaemia (Jeffcoate, 1962).

(iii) Haemolytic anaemia (Dacie, 1954).

(iv) Collagen disease (Catterall, 1961; Moore and Lutz, 1955; Moore and Mohr, 1952).

(v) Chronic infection (e.g. brucellosis: Carpenter, Miller, Boak, and Heiskell, 1961).

(vi) Chronic granulomata (e.g. leprosy: Ruge, Fromm, Fuhner, and Guinto, 1960).

(vii) Drug addiction (narcotics: Boak, Carpenter, and Miller, 1961).

(viii) Pre-eclamptic toxaemia (Wilkinson, 1959).

(ix) Pregnancy, trypanosomiasis, mycoplasmal pneumonia (Walter and Israel, 1965).

$(x)$ Virus infection (e.g. virus pneumonia, glandular fever, infective hepatitis, smallpox vaccination: Dickinson, 1957).

In the present series chronic malaria was frequently found.

Yaws and Syphilis It was difficult to differentiate between syphilis and a previous yaws infection (Wilkinson, 1966).

Jeffcoate (1962) stated that TPI and RPCF tests can help to distinguish syphilis from yaws, but this is not the common experience of venereologists. To overcome this special difficulty CSF examinations were carried out on the Nigerian patients. Yaws is not known to affect the central nervous system or to cross the placental barrier. A positive CSF test or any evidence of foetal infection is therefore diagnostic of syphilis, but negative findings do not exclude it (Miller, Slatkin, Meyer, and Silides, 1960). The fact that yaws and syphilis may co-exist (Beerman, Nicholas, Schamberg, and Greenberg, 1962) complicates the issue. Case 3 (Table III) had healed skin lesions of yaws as well as positive CSF findings, and had obviously had both yaws and neurosyphilis.

Neurosyphilis Harris, Bossak, Deacon, and Bunch (1960) concluded that the FTA was the most sensitive CSF test. There were three Nigerian cases of "proved" neurosyphilis in my series; all had high protein concentrations and high cell counts suggestive of an inflammatory process. All three specimens gave a positive PPR and FTA test and two also gave positive VDRL slide tests. When facilities for FTA tests are not available, positive PPRs and VDRL slide tests may be useful indications of neurosyphilis.

Placenta and Cord In two cases in which the foetus was dead at full term, the histology of the placenta and cord was nearer to the classical picture of syphilis than that of the placenta in five other pregnancies lost at about the 25th week. This conflicts with the conclusion of McCord (1934). On the whole, diagnosis by histological examination had only a limited application (Haines and Taylor, 1962).

"Hyper-placentosis" and PET in Syphilitic Patients The statement of Parviainen (1945) that a woman with more than one placenta is more likely to have PET is in accord with the day-to-day clinical experience of many obstetricians. Browne (1957) stated that the weight of the placenta was greater in PET than in normal cases. Chun, Braga, Chow, and Lok (1964) observed that the bigger and more active a placental hydatiform mole was, the more frequent and more severe was an associated PET. Jeffcoate and Scott (1959) found a bigger placenta in relation to foetal weight in cases of hydrops foetalis. That the placenta is heavier in syphilitics than in normal patients is well documented.

The possibility should be considered that the high incidence of PET among proved and probable cases of syphilis in this series may be explained on the basis of "hyper-placentosis". Certainly none of the placentae weighed less than a quarter of the baby's birth weight.

Foetal Loss Syphilis ranks high as a cause of abortion. It is frequently stated that foetal loss from untreated syphilitic infection occurs around the 20th week of pregnancy. It is little emphasized how often the foetuses of syphilitic mothers die and are extruded at an early embryonic stage. Many syphilitic patients have been pregnant without even knowing it -the typical history being merely one of irregular menstruation. When a woman with florid untreated syphilis becomes pregnant there is about a 75 per cent. chance of an abortion or an intra-uterine foetal death. Syphilis is lethal in the early embryonic formative stage because of its predilection for developing neural tissues.

It is not clear, however, why eight pregnancies were lost in the present series, despite adequate treatment. Penicillin resistant strains of $T$. pallidum might have been present or the penicillin used might have lost its potency, but the latter is unlikely in two countries as far apart as Ireland and Nigeria and with two different brands of penicillin (Tryplopen and Procaine penicillin). The problem of penicillin resistance to $T$. pallidum requires further study.

Foetal loss may also be due to placental insufficiency. The syphilitic placenta cannot be expected to be very efficient if it had already suffered the irreversible changes of massive fibrosis and endarteritis obliterans. No treatment, however thorough, can influence the course of events in such cases. 
Congenital and Third Generation Syphilis Despite repeated adequate treatment, all the siblings ( 3 brothers and two sisters) of Case 6 (Table II) were sero-positive at ages ranging from 18 to 30 years. In two of them, a diagnosis of congenital syphilis was made at 5 and 6 years of age, and in the other three early diagnosis had been made and treatment given. The persistence of sero-positivity in congenital syphilis depends upon the stage the disease has reached when treatment is started. Infections in babies behave like early syphilis in adults and sero-reversal usually occurs after treatment. If the congenital condition is not diagnosed until puberty or adult life, most cases remain sero-positive for many years, if not for life (Wilkinson, 1967).

The cord blood of this patient's baby was seropositive, but as the infant was a stillborn anencephalic it was not possible to carry out any later investigations. The evidence for third generation syphilis is flimsy, and the condition must be very rare (Nelson, 1964; Beeson and McDermott, 1963). If a maternal infection is indisputably of congenital origin, there is no indication to treat the child although serological tests at about 3 months of age might be advisable.

\section{Summary}

(1) $110 \mathrm{Rh}$-positive women in whom positive Kahn and Wassermann reactions were found at antenatal clinics were further investigated. The results of these investigations are given and discussed.

(2) Twelve cases of proved and eight of probable syphilis were found. All these twenty cases, their husbands, and two affected infants were fully investigated and treated. Only thirteen of the twenty husbands were sero-positive. Three brothers and two sisters of a congenital syphilitic were treated.

(3) 23 patients had previously had yaws. 67 (8 Irish and 59 Nigerian) gave biological false positive results, and 42 of these were thought to be due to chronic malaria because the reagin antibodies disappeared after anti-malarial treatment, no cause being found in the remaining 25 cases.

(4) Histological examinations of placentae and cord tissues and $x$ rays of the long bones helped to decide whether or not a baby was affected and should be treated.

(5) There was a curious association between syphilitic infection and pre-eclamptic toxaemia, which might be explained on the basis of "hyper-placentosis".
(6) A positive reagin test, even on a single occasion, must be reviewed with suspicion.

(7) Foetal losses which occurred despite adequate penicillin therapy may have been due to placental insufficiency.

(8) The Wassermann reaction and Kahn test are reliable screening procedures for syphilis. The TPI is the most reliable diagnostic serum test. The FTA is the most sensitive detector of antibodies in cerebrospinal fluid. The Reiter protein complement-fixation test is useful in diagnosis in countries where more refined tests are not available or are too expensive.

I wish to thank Prof. E. W. L. Thompson and Dr J. B. Akingba of Lagos University Teaching Hospital, the nursing staff of Suru-Lere Health Centre, and Dr T. D. Hanratty and the staff of St. Kevin's Hospital, Dublin, Eire, for their valued encouragement and co-operation, without which it would have been impossible to carry out these investigations.

Prof. Vegas Pires, Prof. Njoku-Obi, Prof. Sheila Fleming, Dr Femi Odunjo, and Dr Sola Okuwobi, all of Lagos University Teaching Hospital, helped in varied ways at different stages of the work.

Dr A.E. Wilkinson of the V.D.R. Laboratory, London, was generous with his advice and kindly carried out the FTA and TPI tests.

\section{REFERENCES}

Beerman, H., Nicholas, L., Schamberg, I. L., and Greenberg, M. S. (1962). Arch. intern. Med., 109, 323.

Beeson, P. B., and McDermott, W. (editors) (1963). "Cecil-Loeb Textbook of Medicine", 11th ed., p. 357. Saunders, Philadelphia and London.

Boak, R. A., Carpenter, C. M., and Miller, J. N. (1961). f. Amer. med. Ass., 175, 326.

Boyd, W. (1961). "A Textbook of Pathology", 7th ed., p. 299. Kimpton, London.

Browne, F. J., and Browne, J. C. McClure (1960). "Antenatal and Postnatal Care", 9th ed. Churchill, London.

Browne, J. C. McClure (1957). Proc. roy. Soc. Med., 50, 787.

Carpenter, C. M., Miller, J. N., Boak, R. A., and Heiskell, G. L. (1961). Amer. F. med. Sci., 241, 231.

Catterall, R. D. (1961). Quart. F. Med., 30, 41.

Chun, D., Braga, C., Chow, C., and Lok, L. (1964). F. Obstet. Gynaec. Brit. Cwlth, 71, 180, 185.

Cunningham, J. F. (1958). "Textbook of Obstetrics", 3rd ed., p. 182. Heinemann. London.

Dacie, J. V. (1954). "The Haemolytic Anaemias". Churchill, London.

Dickinson, C. J. (1957). "Clinical Pathology Data", 2nd ed., p. 64. Blackwell Scientific Publications, Oxford.

Donald, I. (1964). "Practical Obstetric Problems", 3rd ed., p. 72. Lloyd-Luke, London.

Fiumara, N. J. (1960). Publ. Hlth Rep. (Wash.), 75, 1011. 
French, E. B., and Macleod, J. G. (1963), In "The Principles and Practice of Medicine", by Sir Stanley Davidson, 6th ed. reprint, p. 59. Livingstone, Edinburgh.

Greenhill, J. P. (1960). "Obstetrics”, 12th ed., p. 506. Saunders, Philadelphia.

Haines, M., and Taylor, C. W. (1962). "Gynaecological Pathology", p. 354. Churchill, London.

Harris, A., Bossak, H. M., Deacon, W. E., and Bunch, W. L., Jr. (1960). Brit F. vener. Dis., 36, 178.

Holland, P. J. (1965). Personal communication.

Illingworth, C. F. W. (1959). "A Short Textbook of Surgery", 7th ed., p. 32. Churchill, London.

Jeffcoate, T. N. A. (1962). "Principles of Gynaecology", 2nd ed., p. 329. Butterworth, London.

- (1966). Proc. roy. Soc. Med., 59, 397.

— and Scott, J. S. (1959). Amer. F. Obstet. Gynec., 77, 475.

McCord, J. R. (1934). Ibid., 28, 743.

Miller, J. L., Slatkin, M. H., Meyer, P. G., and Silides, D. (1960). Wld Neurol., 1, 434.

Moore, J. E., and Lutz, W. B. (1955). F. chron. Dis., 1, 297.

- and Mohr, C. F. (1952).F. Amer. med. Ass., 150, 467.

Nelson, W. E. (1964). "Textbook of Pediatrics", 8th ed., p. 522. Saunders, Philadelphia.

Parviainen, S. (1945). Acta obstet. gynaec. scand., 25, 32.

Price, I. N. Orpwood (1955). "Clinical Pathology in General Practice", p. 176. B.M.A., London.

Ruge, H. G. S., Fromm, C., Fuhner, F., and Guinto, R. S. (1960). Bull. Wld Hlth Org., 23, 793.

Stallworthy, J., and Bourne, G. (1966). "Recent Advances in Obstetrics and Gynaecology", 11 th ed., p. 16. Churchill, London.

Taylor, C. W. (1966). Personal communication.

Walter, J. B., and Israel, M. S. (1965). "General Pathology", 2nd ed., p. 363. Churchill, London.

Wilkinson, A. E. (1959). Brit. F. vener. Dis., 35, 162.

- (1966). Personal communication. (1967). Personal communication.

- and Sequeira, P. J. L. (1955). Brit. F. vener. Dis., 31, 143.

Woody, N. C., Sistrunk, W. F., and Platou, R. V. (1964). F. Pediat., 64, 63.
RÉSUMÉ

(1) 110 femmes $\mathrm{Rh}$-positives se présentant aux dispensaires prénatals et donnant des réactions positives de Wassermann et de Kahn ont été examinées plus à fond. Les résultats de ces examens sont donnés et discutés.

(2) 12 cas de syphilis demontrée et 8 cas de syphilis probable ont été rencontrés. Ces 20 cas ainsi que leurs maris et deux enfants atteints de syphilis ont été examinés à fond et traités. Seulement 13 des 20 maris étaient séro-positifs. Trois frères et deux soeurs d'un syphilitique congénital ont été soignés.

(3) 23 malades avaient été atteints auparavant de pian. 67 avaient donné des résultats biologiques pseudopositifs, et on a pensé que 42 des 67 résultats étaient dûs à la malaria chronique car les anticorps de réagine avaient disparu après le traitement anti-paludéen, aucune raison n'ayant été trouvée chez les 25 autres cas.

(4) Les examens histologiques du placenta et des tissus du cordon, et la radiographie des longs os ont permis de décider si un bébé était atteint ou non et s'il devrait être traité.

(5) Il y avait une curieuse association entre l'infection syphilitique et la toxémie pré-éclamptique et cela pourrait être expliquée sur la base d'une "hyperplacentose".

(6) Une réaction de réagine positive, même obtenue qu'une seule fois, devra être considerée comme suspect.

(7) Des pertes inexpliquées de foetus avaient eu lieu malgré un traitement adéquat à la penicilline.

(8) La réaction de Wassermann et le test de Kahn sont des procédés sur lesquels on peut compter pour dépister les cas de syphilis. Le test TPI est le test sérologique le plus sûr. Le test FTA est le plus sensible pour détecter les anticorps dans le liquide céphalo-rachidien. Le test de fixation du complément de la protéine de Reiter est utile pour le diagnostic dans les pays où d'autres tests plus précis sont coûteux ou ne sont pas disponibles. 